\title{
Revenue Reserves and Financial Performance in the Brewery Industry: Evidence from Nigeria.
}

\author{
Michael Chidiebere, Ekwe ${ }^{1} \&$ Oliver Ike Inyiama ${ }^{2}$ \\ ${ }^{1}$ Department of Accounting, Michael Okpara University of Agriculture, Umudike, Abia State of Nigeria \\ ${ }^{2}$ Department of Accountancy, Enugu State University of Science \& Technology, Enugu State of Nigeria \\ Correspondence: Michael Chidiebere, Ekwe, Department of Accounting, Michael Okpara University ofAgriculture, \\ Umudike, Abia State of Nigeria. E-mail: ekwemike@yahoo.com
}

Received: September 9, 2014

Accepted: October 15, 2014

Available online: October 29, 2014

doi:10.11114/aef.v1i2.571

URL: http://dx.doi.org/10.11114/aef.v1i2.571

\begin{abstract}
The research evaluates the co-integration, magnitude and strength of the relationships between corporate retentions as proxied by retained earnings and some key financial performance indicators, in the Nigeria manufacturing industry using the Brewery sub-sector as a focal point. The ex- post facto research designed which made use of secondary data obtained from annual reports and accounts of the two market leaders in the sector: Nigeria Breweries Plc and Guinness Nigeria Plc, from year 2000 to 2013.The magnitude of association of the variables was validated using the ordinary least squares method. Augmented Dickey- Fuller (ADF) test was also conducted on all the variables to check for stationary of time series data. Log of retained earnings, current asset ratio, dividend per share attained stationary at first difference, while earnings per share, net asset value per share, price -to- earnings ratio and market price of equity shares, achieved stationary at second difference. Results indicate that a strong relationship (about 77\%) exist between retained earnings and net asset value per share. Also long run relationship exists between retained earnings, and the rest of the variables implying that, if the retained earnings are properly invested, the returns will catalyze growth, development and expansion of the firms while the financial performance indicators will serve as predictors to the appropriate levels of retentions and investment which could guarantee good bottom line without incurring the opportunity cost of excess liquidity.
\end{abstract}

Keywords: Corporate Retentions, Financial Performance, EPS, NAVPS, Nigeria Brewery Industry

\section{Introduction}

\subsection{Background of the Study}

Companies all over the world are increasingly becoming aware of the importance of financial management, with emphasis on investment and retention policies, as a veritable tool for efficient business management. It is the responsibility of the management to establish these corporate policies for effective and efficient internal control, performance evaluation and reserve management. Business managers evolve flexible and feasible financial policies to ensure the realization of its corporate targets (Nwude, 2007).

Reserves are made by companies mainly for investment into areas that promises some growth opportunities. This may include the acquisition of plant and machineries, establishment of new production lines, diversification of products and business, establishment of new branch offices, acquisition of a company to widen its distribution base and so on. Activist stockholders and corporate governance specialists express concern that large cash holdings reduce disciplinary pressure on managers and expose them to the temptation of spending cash even when profitable investment opportunities are not available. Mikkelson and Partch (2003) document that managers of cash-rich firms cite the benefits of having cash on hand as a reserve to fund large capital investments and expenditures, resulting from less internal financing costs. The intention to fulfill the expectations of investors and financial markets increasingly dominates reserve accumulation motives which, as Shayne (2013) opines, is the cornerstone of financial flexibility.

Companies are expected to strategically allocate their assets/wealth to meet its long term investment need that could guarantee stability and growth and optimize the risk/return trade-off. In support, Dominguez (2011) affirms that, although it is to be expected that a strategic asset allocation decision will be effective over the medium to long term, the 
allocation might be reviewed and revised in the light of changing investment opportunities. Asset allocation decisions could however be pursued through sound retention and investment policies in terms of the magnitude and nature of reserves and provisions to be created.

Retained earnings (revenue reserves) which as opine by Kim and Suh (2010) is the accumulated net income that is retained by a firm rather than distributed to its shareholders as dividends, is one of the key retentions created by companies especially in the brewery sector. Retained earnings is the percentage of net profits not paid out as dividends, but retained by the company to be reinvested in its core business or to pay debt while Investopedia (2014) describes it as retained surplus or retention ratio which equals the beginning retained earnings plus net income less dividends.Dividend decision also involves the determination of the proportion of a company's earnings (profit) to pay out as dividend to the shareholders or retained within the firm for self-financing (Onuorah and Ezeji 2013).

Breweries in Nigeria especially the Nigeria Breweries Plc and Guinness Nigeria Plc create reserves for long-term capital investment projects or other large anticipated future expenditures. The reserve is made to guarantee availability of fund to finance their anticipated projects which might include fixed asset replacements that are neither treated as expenditure on purchase of goods nor period expenses. The two breweries mentioned above are the leaders of the highly capital intensive industry in Nigeria which largely automated their production lines. They invest so much on heavy equipments and fixed assets resulting in huge capital outlay which has to be accumulated over time.

Considering that some of these revenue retentions could exert significant impact on financial performance and shareholder's equity of firms in Nigeria brewery industry, the study attempts to ascertain whether there is a relationship as well as the strength of the relationship, where it exists, between revenue retentions and selected industry financial performance indicators. Such a quantitative process, in our opinion, will be of tremendous importance in determining the nature and magnitude of corporate retentions with emphasis on retained earnings they influence performance and investments in Nigeria brewery industry.

\subsection{Statement of the Problem}

Business organizations such as firms in the Nigeria brewery sector require fixed assets such as Land, buildings, plant and machinery, furniture and fittings, motor vehicles and office equipments for their productive activities. These assets could be sourced through acquisitions using the capital contributed by equity shareholders, financed by loans, take up the assets on lease or hire purchase, or financed internally through retained earnings.

Nevertheless, it must be noted that each of these modes of financing has far reaching implications on the firm. When funds are raised through the sale of equity shares, it tends to dilute the pattern of ownership and by extension, could lead to monumental changes in board composition and executive management. Sourcing funds through loans require collateral and accumulates interest and may lead to liquidation in the event of default. When fixed assets are taken up on lease arrangements, it attracts lease rental just as hire purchase financing also accumulates interest with the bigger risk of repossession in case of default. On the other hand, corporate financing, through retained earnings is one main source of internal financing and firms prefer internal financing because of its low risk profile (Myers and Majluf, 1984).Thirumalaisamy (2013) further affirms that retained earnings are the most important sources of financing growth of a firm. Cost of funds generated internally is almost insignificant where at all, it exists.

Citing DeAngelo, DeAngelo and Stulz (2006) who considered retained earnings to be a determinant of dividends, Kim and Suh (2010) submits that although retained earnings are a key item in shareholders' equity, corporate finance literature has paid little attention to this variable. Thirumalaisamy (2013) emphasized that retained earnings played a significant role in the corporate India financing pattern. In support of this argument, Iga (2008) opines that unless a firm consciously and explicitly intends not to replace certain assets, or is prepared to operate with less or lower standard assets and provide less or lower standards of services in future, it should always strive to ensure that operating revenue matches operating expenses.

Sequel to the importance attached to revenue reserves in corporate project financing, coupled with very little research attention paid in this area, this study attempts to examine the relationship: correlation, causalities and sustainability of long run relationship between corporate revenue reserves as proxied by retained earnings and selected financial performance indicators in the Nigeria brewery industry.

\subsection{Objectives of the Study}

The main objective of the study is to assess the extent to which corporate reserves, such as retained earnings are associated with selected key financial performance indicators (KFPI) in Nigeria brewery industry.

The specific objectives of the paper include:

a) To examine the extent to which Net Asset Value Per Share (NAVPS) is related to corporate retained earnings in the Nigeria brewery industry. 
b) To validate the relationship between Earnings per Share (EPS) and retained earnings and in the Nigeria brewery industry.

c) To examine the level of association between Market Value of Equity Shares (MVPS) and corporate retained earnings in the Nigeria brewery industry.

d) To ascertain the extent to which corporate retained earnings influence price-to-equity ratios of firms in the Nigeria brewery industry.

e) To evaluate the relationship between dividend per share (DPS) and corporate retained earnings in the Nigeria brewery industry.

f) To check whether current ratio (working capital ratio) is related to corporate retained earnings in the Nigeria brewery industry.

\section{Review of Related Literature}

\subsection{Theoretical Framework}

The paper is underpinned on the Lifecycle theory, Pecking Order theory and the signaling theory. Lifecycle theory contends that dividend policy is driven by the tradeoff between distribution and retention of corporate earnings and this tradeoff depends on firm maturity stage. Pecking Order theory submits that firms prefer internal funds first, debt second and external equity last and that funding needs and internal funds jointly determine capital structure decisions. Simply put, the model states that firm's capital structure choices follow a hierarchy; firms first prefer internal financing, then choose debt when internal financing is not available, and only choose equity as a last resort. The firm maturity stage enters the picture because it is believed that young firms rely more on new equity (or contributed equity) for early growth while mature firms rely more on self-financing through corporate retentions and are more able to pay dividends because of ample accumulated earnings.

Citing Miller and Modigliani (1961), Tsuji (2012) suggested that the information content of dividend policy should apply. This means that if managements' future earnings expectations affect their current dividend payouts decisions, then dividend changes will convey information to the market regarding future earnings. Allen and Michaely (2003) as cited in Tsuji (2012) also documented that the dividend-information/signaling hypotheses included three important implications that had been empirically examined:

1. Unanticipated dividend changes should be accompanied by stock-price changes in the same direction.

2. Dividend changes should be followed by subsequent earnings changes in the same direction.

3. Unanticipated changes in dividends should be followed by revisions in the market's expectations of future earnings in the same direction as the dividend change.

\subsection{Retained Earnings and Firm Performance}

Applying the standard cash-in-advance framework, Retained Earnings and the Real Effects of Monetary Shocks was examined by Doepke (2004) submitted that another key feature of an economy is that the business sector accumulates retained earnings and credits profits and dividends to the consumers and other stakeholders only with a delay. This is because the bottom line can only be determined at the end of the accounting year leading to proposing the year's dividend in arrears, thus, the delay. The study concludes that retained earnings matter for the transmission of monetary policy because they affect the overall balance between different uses of funds in the economy and that corporate profits react quickly to a monetary shock, whereas dividend payments adjust only after a considerable delay. Since the shareholders own the firms, in a frictionless model, they would consider retained earnings as equivalent to their own savings.

Segal and Spivak (1986) did a study on firm size and optimal growth rate through reinvestment of retentions and concluded that by retaining earnings and reinvesting them in the firm, the firm can change the parameters governing the stochastic process, increasing the probability of multiplication and reducing the probability of disappearance. Thus the firm's decision variable is the size of the retained earnings.

To confirm that firms manage earnings upwards when they anticipate that "pre-managed" earnings will be lower than expected dividend payments, Daniel, Denis and Naveen (2007) found that firms whose discretionary accruals cause reported earnings to exceed expected dividend levels are significantly less likely to cut dividends than are firms whose reported earnings fall short of expected dividend levels. Collectively, they argue that their findings imply that managers treat expected dividend levels as an important earnings threshold.

A Growth Type Explanation for Persistence in Retained Earnings and Propensity to Pay Dividends was sought by Wu and Yeung (2010). The study reveals that while firms that typically pay dividends already have high ratios of retained earnings-to-total-equity (RE/TE) and high propensities to pay (PTP) early on, firms that typically do not pay dividends have persistently low RE/TE and low PTP even after 20 years of growth. They argued that the growth type view can 
explain why low RE/TE and PTP can be surprisingly long-lived, and suggests that typical non-payers deliberately do not pay dividends even when they can, because doing so may confuse the market.

To delineate how the interaction between funding needs and internal funds results in the cross-sectional heterogeneity in leverage, Kim and Suh (2010) examined the interactions between retained earnings and capital structure. Along the dimension of retained earnings, they identified three groups of firms:

(i) low-Retained Earnings (RE) firms which are low-levered because of a heavy reliance on external equity,

(ii) medium-RE firms which are high-levered because of active use of debt in funding fast growth, and

(iii) high-RE firms which are low-levered because internal funds exceed funding needs.

They found that retained earnings convey information about both funding needs (i.e., asset growth) and internal funds and that the inverted-U-shaped relation is an outcome of the interplay between these two factors. They submitted that the relation between leverage and profitability is also inverted-U-shaped and reflects a similar interplay between funding needs and internal funds.

With the application of correlation and multiple regression approach the relationship between firm growth and retained earnings was examined by Thirumalaisamy (2013). The study reveals that growth of corporate firms in India is substantially financed by retained earnings and that there is no transaction and bankruptcy costs associated with retained profits which made it a major internal source of finance for companies. When a firm has potential growth opportunities, there tend to be greater demand on internally generated funds accumulated through retentions. Their results suggest that across the classifications of sample companies cash flow and dividend are found to be the most influencing variables on retained earnings and companies with low investment opportunities for growth and expansion prefer to distribute much of their earnings as dividend. They emphasized that potential investment opportunities are likely to arise far off in the future for these companies. This implies that profit, if retained, remains unutilized for long time or utilized in short-term investment opportunities which would yield low return on investment and such companies would prefer to pay out the earnings and raise capital whenever needed. Hence, they concluded that the level of earnings retained is very much influenced by the growth rate of the companies.

In compliance with the signalling theory, Khan (2009) examined the Determinants of Share Price Movements in Bangladesh with emphasis on Dividends and Retained Earnings. The study strives to establish the relative importance of dividends, retained earnings, and other determinants in the explanation of stock prices in Bangladesh with particular stock price of the companies associated with Dhaka Stock Exchange (henceforth DSE), an emerging capital market of Bangladesh. The study applied dividend theory, information contents, theory of information asymmetry, signalling theory, clientele effect theory to explain the basic concepts that is used to analyze the results. The study found that dividends, retained earnings and other determinants have dynamic relationship with market share price. Findings also suggest that the overall impact of dividend on stock prices is comparatively better that that of retained earnings and that expected dividends play an important role in the determination of stock prices whatever determinants, like lagged price earnings ratio or lagged price, are considered.

\subsection{Statement of Hypotheses}

Following from the issues discussed above and the works reviewed, this paper hypothesizes that:

i) $\mathrm{H}_{\mathrm{O}}$ : There is no significant relationship between net asset value per share and corporate retained earnings in the Nigeria brewery industry.

ii) $\mathrm{H}_{\mathrm{O}}$ : Earnings Per Share is not significantly associated with corporate retained earnings in the Nigeria brewery industry.

iii) $\mathrm{H}_{\mathrm{O}}$ : There is no significant relationship between the market value of equity shares and corporate retained earnings in the Nigeria brewery industry.

iv) $\mathrm{H}_{\mathrm{O}}$ : Price-to Earnings Ratio is not significantly related to corporate retained earnings in the Nigeria brewery industry.

v) $\mathrm{H}_{\mathrm{O}}$ : There is no significant relationship between Dividends per Share and corporate retained earnings in the Nigeria brewery industry.

vi) $\mathrm{H}_{\mathrm{O}}$ : Current Ratio is not significantly influenced by corporate retained earnings in the Nigeria brewery industry.

The dependent and independent variables under study and the nature of association as suggested, are considered as a result of their role in giving meaning to corporate retentions as a function of key performance indicators (KPI), their role in the theoretical framework of the study, availability of data for analysis and their use in reviewing related literature. 


\section{Methodology}

\subsection{Research Design}

The paper is an ex post facto research which provides a systematic and empirical solution to research problems, by using data which are already in existence. A variant of the multivariate regressions used by Mikkelson and Partch (2003), Dutta and Reichelstein (2001), Khan (2009) and Thirumalaisamy (2013) was adopted in this study. Accordingly, the magnitude and nature of the relationship between firm performance and corporate retentions (retained earnings) was determined using multiple regressions. Data for analysis on the performance of firms in the Nigeria brewery industry were extracted from the annual report and accounts of Nigeria Breweries Plc and that of Guinness Nigeria Plc between 2000 and 2013.

\subsection{Description of Research Variables}

The research variables were structured into dependent and independent variables for the purpose of the analysis; though the main concern is to evaluate the nature, magnitude and strength of their interactions between the variables. The independent variables of the study are the Market Share Price (MSP), Earnings Per Share (EPS), Net Asset Value Per Share (NAVPS), Price Earnings Ratio (P/E Ratio), Dividend Per Share (DPS) and Current Asset Ratio (CAR) while Retained Earnings (RE) is the dependent variables.

\subsubsection{Market Share Price (MPS)}

Market Share Price is the value of a firm's equity share. Equity share is the unit of ownership of a company. The shares are sold to generate fund for expansion, diversification and investment. Price of equity shares is determined ultimately through the interactions of the forces of demand and supply.

\subsubsection{Earnings Per Share (EPS)}

When a company shows convincing signs that it has the capacity and potentials of earnings especially in the long term, investors are most likely to be attracted to such company which could lead to an increase in its earnings per share. Earnings Per Share is calculated by dividing the company's total earnings or income by the number of shares the company has outstanding. Total earnings are proxied in this paper by Profit before Interest and Taxation (PBIT).

\subsubsection{Net Asset Value per Share (NAVPS)}

Net asset value per share (NAVPS) is the value of a firm's total assets (fixed and current assets) less the value of its liabilities (long and short term liabilities) divided by the number of outstanding equity shares. It is an acceptable yardstick for estimating the performance of companies with respect to the property and investment of the companies.

\subsubsection{Price - Earnings Ratio (P/E Ratio)}

Investors apply this ratio to determine whether to invest in a particular company or not. Price-Earnings ratio is calculated as Market Price per equity Share divided by Earnings per Share. It reveals the amount which investors are to pay for every one naira of earnings. When the Price to Earnings ratio is low, investors are more willing to invest than when the ratio is high. When the P/E ratio is low, investors will pay less for every one naira of earnings and as a result, more savings are made to address other financial issues.

\subsubsection{Dividend Per Share (DPS)}

Dividend per Share is the sum of declared dividends for every ordinary share issued divided by total outstanding equity shares. It is the total dividend paid to equity shareholders over an accounting year (including interim dividends) divided by the number of outstanding ordinary shares issued. Profit is distributed to equity shareholders through dividend payouts. A consistent growth in dividend per share is a good signal as supported by signaling theory that the firm could sustain her growth even in the long term.

\subsubsection{Current Asset Ratio (CAR)}

The current ratio is an indication of a firm's market liquidity and ability to meet creditor's demands. Acceptable current ratios vary from industry to industry and are generally between 1.5 and 3 for healthy businesses. If a company's current ratio is in this range, then it generally indicates good short-term financial strength. If current liabilities exceed current assets (the current ratio is below 1), then the company may have problems meeting its short-term obligations. If the current ratio is too high, then the company may not be efficiently using its current assets or its short-term financing facilities. This may also indicate problems in working capital management.

\subsubsection{Retained Earnings (RE)}

Retained earnings refer to the portion of net income of a firm that is retained by the firm rather than distributed to shareholders as dividends. In the event of loss, the accumulated retained earnings of the firm are reduced by the amount of the loss. However, if the balance of the retained earnings account is negative it may be called retained losses, accumulated 
losses or accumulated deficit. Retained earnings and losses are cumulative from year to year and reported in the shareholder's equity department of the corporation's balance sheet.

\subsection{Model Specification}

The multiple regression (prediction) models were statistically written as,

$$
\log \mathrm{RE}_{\mathrm{t}, \mathrm{i}}=\beta_{\mathrm{o}}+\beta_{1} \mathrm{EPS}_{\mathrm{t}}+\beta_{2} \mathrm{NAVPS}_{\mathrm{t}}+\beta_{3} \mathrm{PE}_{\mathrm{t}}+\beta_{4} \mathrm{DPS}_{\mathrm{t}}+\beta_{5} \mathrm{CAR}_{\mathrm{t}}+\beta_{6} \mathrm{MPS}_{\mathrm{t}}+\mathrm{e}_{\mathrm{t}}
$$

Where:

$\log \mathrm{RE}_{\mathrm{t}, \mathrm{i}}=\log$ of Retained earnings; NAVPS = net asset value per share;

EPS $=$ earnings per share, $\mathrm{PE}=$ price earnings ratio; MPS $=$ market price of shares

$\mathrm{CAR}=$ current asset ratio; DPS $=$ Dividend per Share;

$\beta_{\mathrm{o}}=$ coefficient (constant) to be estimated

$\beta_{\mathrm{i}}-\beta_{6}=$ parameters of the independent variables to be estimated

$\mathrm{t}=$ current period

$\mathrm{e}=$ stochastic disturbance (error) term

\section{Analysis and Discussion of Results}

\subsection{Nigerian Breweries Plc}

The time series data obtained from annual report and accounts of Nigerian Breweries Plc were checked for stationary. If time series data used for analysis are not stationary, it could lead to spurious regression. However, to obtain initial evidence of stationary status before subjecting the data to Augmented Dickey Fuller Test, the following graphical representations were made. The outcome as seen in Figure 1 reveals non stationary status for all the variables because the line graphs failed to cross the zero line severally.

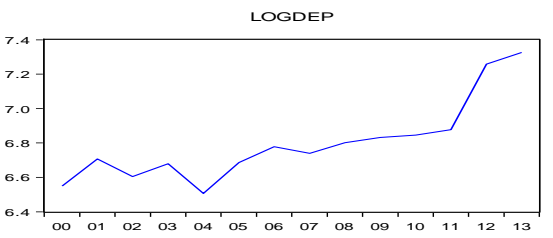

DPS

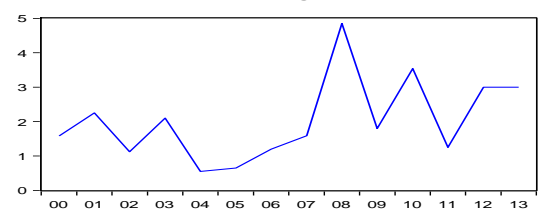

PERATIO

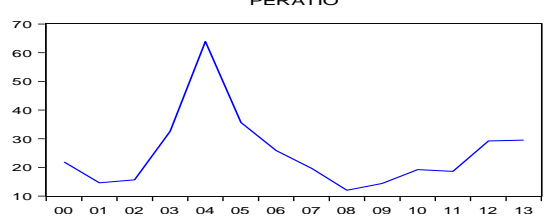

LOGRE

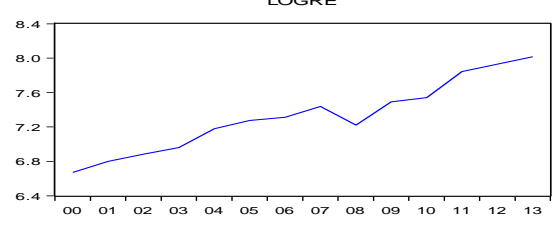

MPS

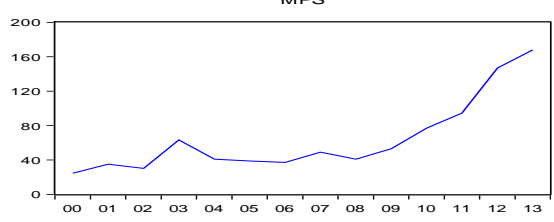

CAR

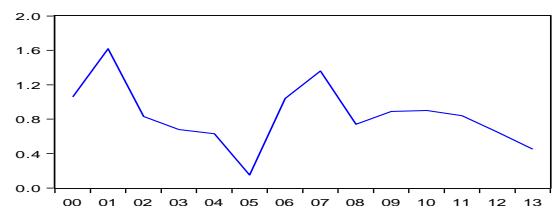

EPS

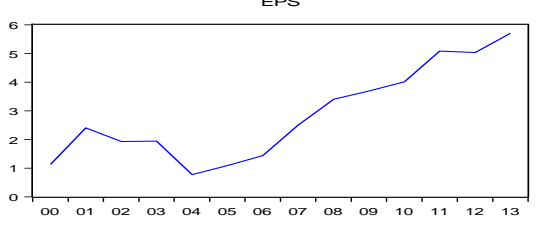

NAVPS

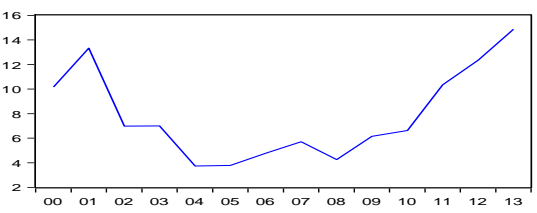

Figure 1. Graphical Representation of the Variables with Unit Root Issues

Source: Author's EView 8.0 Output.

Unit Root Test

The Augmented Dickey Fuller (ADF) procedure was applied in testing for existence of unit root or stationary of time series data and the order of integration of the variables. 
Table 1.Augmented Dickey Fuller (ADF) Unit Root Test Results-Nigerian Breweries Plc

\begin{tabular}{lccccc}
\hline Variables & \multicolumn{2}{c}{ Test Critical Values } & \multicolumn{3}{c}{ TestStatistics Status } \\
\hline LOGRET.EARN & $1 \%$ & $5 \%$ & $10 \%$ & ADF & (Stationary) \\
EPS & -4.121990 & -3.144920 & -2.713751 & -5.227483 & I(1) \\
NAVPS & -4.200056 & -3.175352 & -2.728985 & -6.325721 & $\mathrm{I}(2)$ \\
P/E Ratio & -4.200056 & -3.175352 & -2.728985 & -14.17136 & $\mathrm{I}(2)$ \\
Share Price & -2.816740 & -1.982344 & -1.601144 & -3.558976 & $\mathrm{I}(2)$ \\
CAR & -4.200056 & -3.175352 & -2.728985 & -7.421633 & $\mathrm{I}(2)$ \\
DPS & -4.121990 & -3.144920 & -2.713751 & -4.624207 & $1(1)$ \\
\hline
\end{tabular}

Source: Researcher's EView 8.0 Computation

Table 1 indicates that all the data series are non stationary, meaning that they have unit root. Time series data for Current Assets Ratio, Log of Retained Earnings, Dividend per Share and Log of depreciation achieved stationary at first difference while Earnings per Share, Net Asset Value per Share, Price-to-Earnings Ratio and Market Price of Equity Shares attained stationary at second difference. The graphs that emerged after the differentiation of the series crossed the zero line severally depicting freedom from unit root as shown in Figure 2 below.

DLOGRE

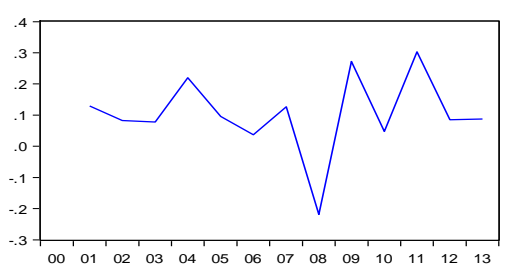

DDPS

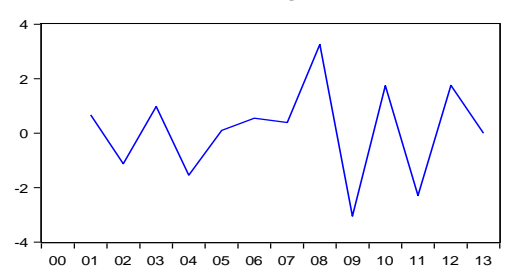

DPERATIO

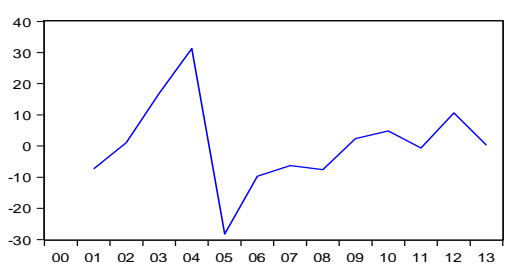

DLOGDEP

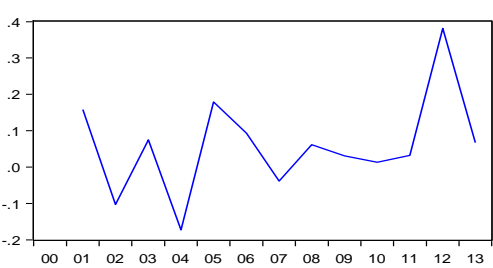

DMPS

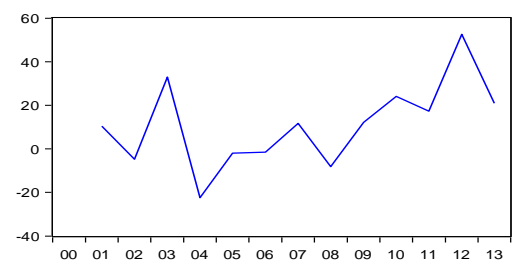

DCAR

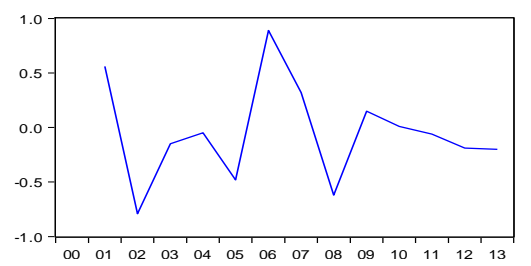

DEPS

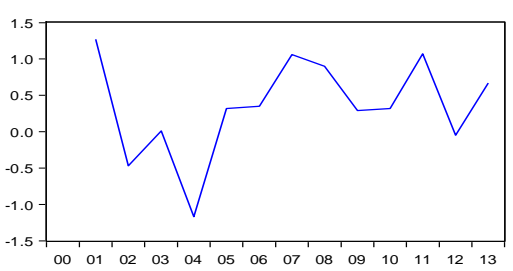

DNAVPS

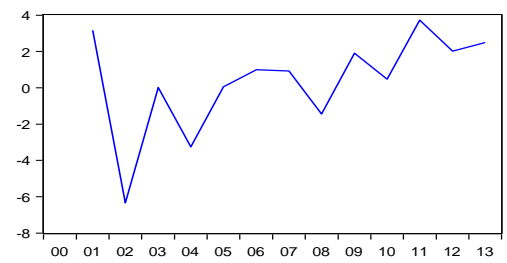

Figure 2. Graphical Representation of the Variables without Unit Root Issues

Source: Author's EView 8.0 Output.

Table 2.Descriptive Statistics of the Variables

\begin{tabular}{lccccccc}
\hline & LOGRE & EPS & DPS & MPS & NAVPS & CAR & PERATIO \\
\hline Mean & 7.326191 & 2.865000 & 2.034286 & 64.22571 & 7.866429 & 0.845714 & 25.18000 \\
Median & 7.294263 & 2.450000 & 1.695000 & 44.92500 & 6.810000 & 0.835000 & 20.74000 \\
Maximum & 8.016865 & 5.700000 & 4.850000 & 167.9000 & 14.86000 & 1.620000 & 63.88000 \\
Minimum & 6.670474 & 0.770000 & 0.550000 & 24.62000 & 3.740000 & 0.150000 & 12.01000 \\
Std. Dev. & 0.417718 & 1.630676 & 1.203730 & 43.92798 & 3.691013 & 0.363418 & 13.33153 \\
Skewness & 0.148162 & 0.393132 & 0.897265 & 1.429552 & 0.620760 & 0.325424 & 1.796764 \\
Kurtosis & 2.050582 & 1.837475 & 3.153047 & 3.770403 & 2.059868 & 3.306498 & 6.103444 \\
Jarque-Bera & 0.577034 & 1.148978 & 1.892194 & 5.114666 & 1.414710 & 0.301902 & 13.15114 \\
Probability & 0.749374 & 0.562993 & 0.388254 & 0.077511 & 0.492946 & 0.859890 & 0.001394 \\
Sum & 102.5667 & 40.11000 & 28.48000 & 899.1600 & 110.1300 & 11.84000 & 352.5200 \\
Sum Sq. Dev. & 2.268354 & 34.56835 & 18.83654 & 25085.67 & 177.1065 & 1.716943 & 2310.485 \\
Observations & 14 & 14 & 14 & 14 & 14 & 14 & 14 \\
\hline
\end{tabular}

Source: Author's EView 8.0 Output. 
Table 2 shows the mean, median, maximum and minimum as well as deviations from the mean of the series of the variables considered in this paper. Skewness coefficients of log of retained earnings, earnings per share, dividend per share, net asset value per share and current asset ratio have values less than 1 . This indicates a normal frequency distribution while market price of shares and price-to-earnings ratio share price have values greater than unity, indicating that the frequency is not normally distributed. Kurtosis coefficient also lends support to this position as market price of shares and price-to-earnings ratio indicate an abnormal distribution with coefficient higher than 3.5. Jarque-Bera statistic indicates an abnormal frequency distribution when the p-value is significant. The p-value is significant at $10 \%$ for market price of shares while it is significant at both $5 \%$ and $10 \%$ for price-to-earnings ratio indicating abnormality in distribution. Market price of shares reveals a very volatile standard deviation followed by price-to-earnings ratio.

Table 3. Regression Analysis - Nigeria Breweries Plc

Dependent Variable: Log of Retained Earnings

\begin{tabular}{crrrr}
\hline Variable & Coefficient & Std. Error & t-Statistic & Prob. \\
\hline DDPS & -0.063402 & 0.010554 & -6.007217 & 0.0010 \\
DCAR & 0.030571 & 0.045909 & 0.665904 & 0.5302 \\
DMPS & 0.001194 & 0.001256 & 0.950374 & 0.3786 \\
DPERATIO & 0.000698 & 0.001581 & 0.441390 & 0.6744 \\
DNAVPS & 0.010383 & 0.013161 & 0.788948 & 0.4602 \\
\multicolumn{1}{c}{ C } & 0.102317 & 0.024141 & 4.238261 & 0.0055 \\
R-squared & 0.908823 & Mean dependent var & 0.103569 \\
Adjusted R-squared & 0.817647 & S.D. dependent var & 0.127783 \\
S.E. of regression & 0.054567 & Akaike info criterion & -2.675036 \\
Sum squared resid & 0.017865 & Schwarz criterion & -2.370833 \\
Log likelihood & 24.38773 & Hannan-Quinn criter. & -2.737564 \\
F-statistic & 9.967734 & Durbin-Watson stat & 2.237934 \\
Prob(F-statistic) & 0.006581 & & \\
\hline
\end{tabular}

Source: Author's EView 8.0 Output.

Equation: Retained Earnings $=0.102317-0.063402(\mathrm{DPS})+0.0 .030571(\mathrm{CAR})+0.001194(\mathrm{MPS})$

$$
+0.000698(\text { PE RATIO })+0.010383(\text { NAVPS })+\text { et }
$$

Table 3indicates that a negative and significant relationship exists between dividend per share and retained earnings in accordance with a priori expectation while negative and insignificant relationships are found between retained earnings and earnings per share, market price of equity shares, net asset value per share, current asset ratio and price-to-earnings ratio. Adjusted $\mathrm{R}^{2}$ reveals that about $82 \%$ of the variations in retained earnings could be explained by the independent variables while about $18 \%$ may be attributable to error term, chance and other variables not considered.

Table 4.Correlation Results- Nigerian Breweries Plc

\begin{tabular}{cccccccc}
\hline & DLOGRE & DEPS & DMPS & DDPS & DCAR & DNAVPS & DPERATIO \\
\hline DLOGRE & 1.000000 & -0.143626 & 0.092692 & -0.874581 & 0.282609 & 0.287451 & 0.271512 \\
DEPS & -0.143626 & 1.000000 & 0.230299 & 0.239499 & 0.306569 & 0.688394 & -0.632168 \\
DMPS & 0.092692 & 0.230299 & 1.000000 & 0.238799 & 0.071738 & 0.561353 & 0.134752 \\
DDPS & -0.874581 & 0.239499 & 0.238799 & 1.000000 & -0.085404 & 0.000793 & -0.176473 \\
DCAR & 0.282609 & 0.306569 & 0.071738 & -0.085404 & 1.000000 & 0.552288 & -0.034119 \\
DNAVPS & 0.287451 & 0.688394 & 0.561353 & 0.000793 & 0.552288 & 1.000000 & -0.241492 \\
DPERATIO & 0.271512 & -0.632168 & 0.134752 & -0.176473 & -0.034119 & -0.241492 & 1.000000
\end{tabular}

Source: Author's EView 8.0 Output. 
Table 4 depicts a positive correlation between retained earnings and market price of shares, current asset ratio and net asset value per share and a negative correlation with earnings per share, dividend per share. However, a very strong relationship (87.5\%) is found between retained earnings and dividend per share and market value of shares $(66.2 \%)$ and net asset value per share (56.2\%). Other variables appear to have weak relationship with retained earnings.

\subsection{Guinness Nigeria Plc}

The time series data obtained from annual report and accounts of Guinness Nigeria Plc were also tested for unit root properties. Figure 3 shows the graphical representations which reveal the presence of unit root as the line graphs of the variables indicate a wide digression from the zero line.

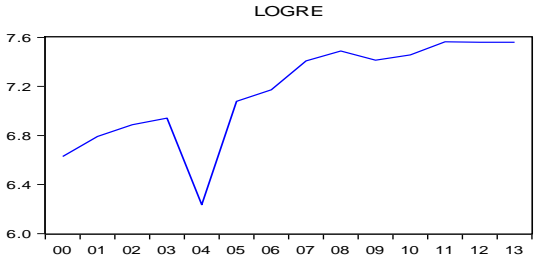

DPS

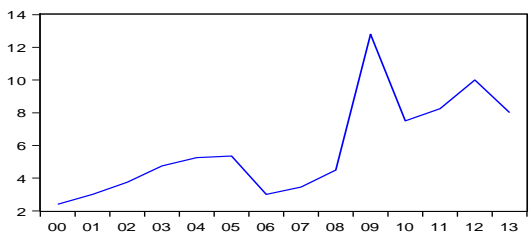

PERATIO

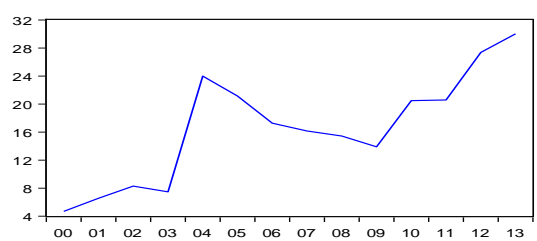

LOGDEP

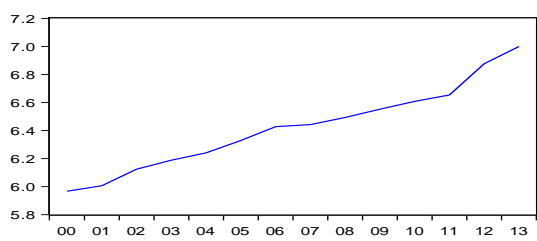

MPS

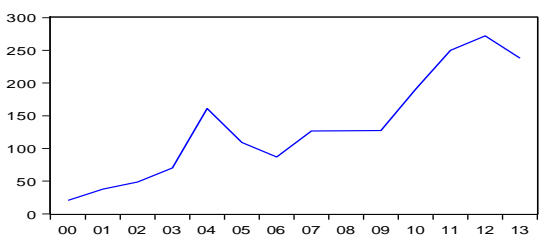

CAR

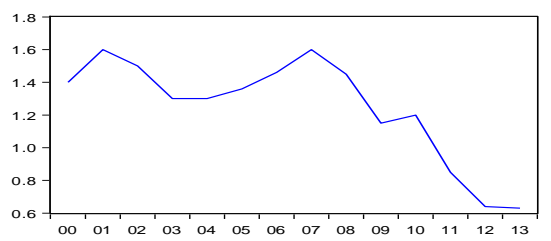

EPS

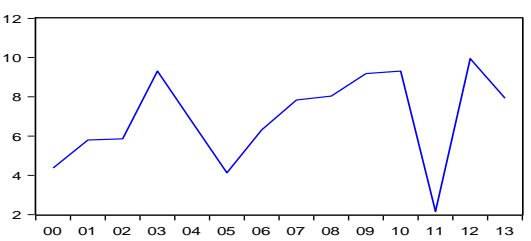

NAVPS

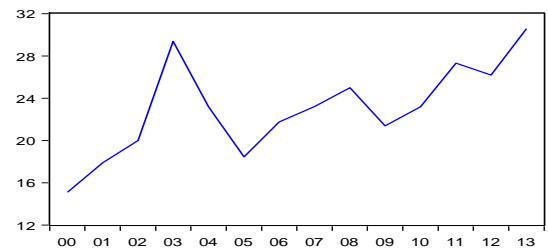

Figure 3. Line Graphs of the Variables with Unit Root Issues

Source: Author's EView 8.0 Output

The Augmented Dickey Fuller test for unit root adopted by this study was applied to determine the stationary status of the time series data and to disinfect the series of their unit root problems, where they exist as shown below.

Table 5.Augmented Dickey Fuller (ADF) Unit Root Test Results-GUINNESS Nigeria Plc

\begin{tabular}{llllll}
\hline \multicolumn{1}{c}{ Variables } & \multicolumn{3}{c}{ Test Critical Values } & \multicolumn{2}{c}{ TestStatistics Status } \\
\hline & $1 \%$ & $5 \%$ & $10 \%$ & ADF & (Stationary) \\
LOGRET.EARN & -4.121990 & -3.144920 & -2.713751 & -5.086614 & $\mathrm{I}(1)$ \\
EPS & -4.057910 & -3.119990 & -2.701103 & -4.087234 & $\mathrm{I}(0)$ \\
NAVPS & -4.297073 & -3.226696 & -2.747676 & -4.356228 & $\mathrm{I}(2)$ \\
P/E Ratio & -4.200056 & -3.175352 & -2.728985 & -5.770319 & $\mathrm{I}(2)$ \\
Share Price & -2.816740 & -1.982344 & -1.601144 & -4.233292 & $1(2)$ \\
CAR & -2.816740, & 1.982644 & -1.601144 & -4.228147 & $1(2)$ \\
DPS & -4.121990 & -3.144920 & -2.713751 & -7.463175 & $1(1)$ \\
\hline
\end{tabular}

Source: Researcher's EView 8.0 Computation

The outcome as shown in Table 5 reveals that retained earnings and dividend per share attained stationary at first difference while net asset value per share, price-to-earnings ratio, market price of shares and current asset ratio achieved stationary at second difference. Earnings per share are stationary at level and intercept. Figure 4 clearly show this new status of the data series as the departure from the zero line by the line graphs has narrowed down in all the cases. 

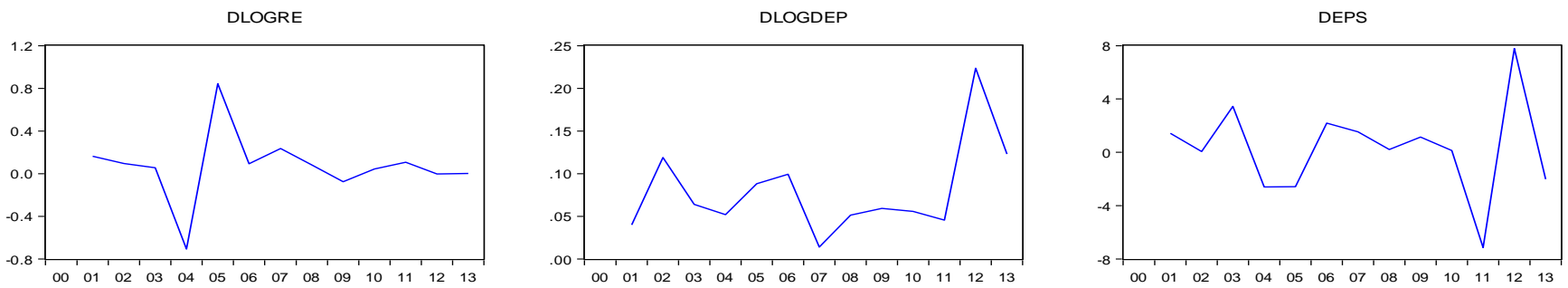

DDPS

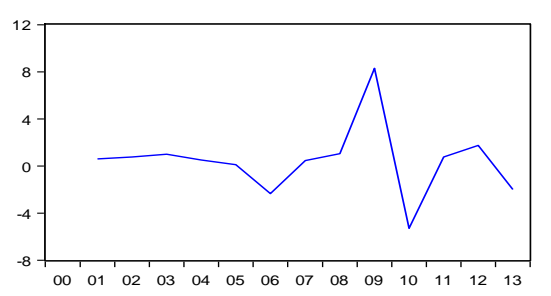

DMPS

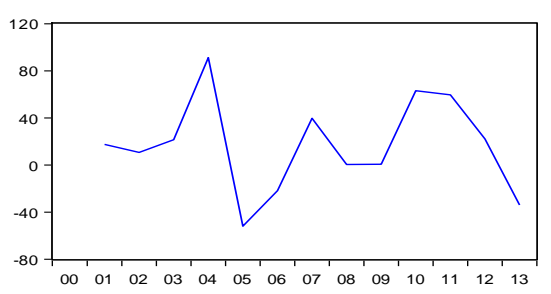

DPERATIO
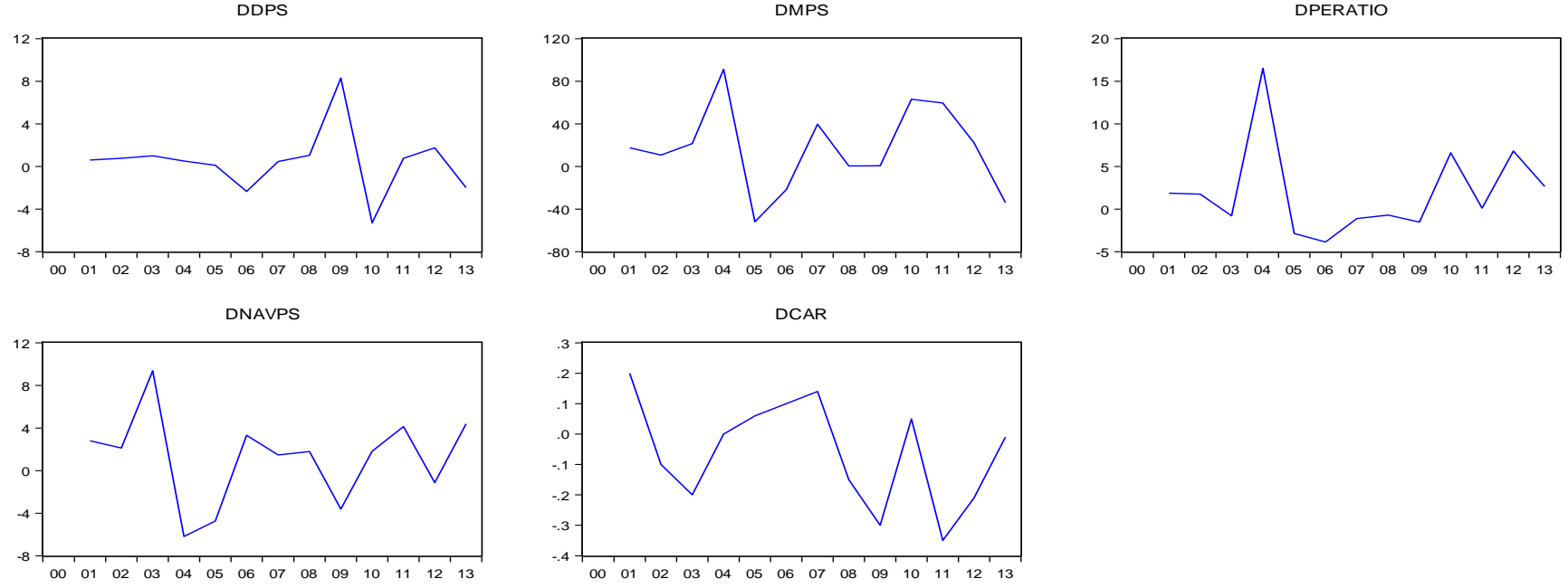

Figure 4. Line Graphs of the Variables without Unit Root Issues

Source: Author's EView 8.0 Output

Table 6.Descriptive Analysis of the Variables

\begin{tabular}{lccccccc}
\hline & LOGRE & EPS & DPS & MPS & NAVPS & CAR & PERATIO \\
\hline Mean & 7.156265 & 6.920714 & 5.857857 & 133.2486 & 23.04000 & 1.245714 & 16.65429 \\
Median & 7.290376 & 7.275000 & 5.000000 & 126.8250 & 23.19000 & 1.330000 & 16.70000 \\
Maximum & 7.563086 & 9.950000 & 12.80000 & 272.1200 & 30.57000 & 1.600000 & 30.01000 \\
Minimum & 6.235229 & 2.160000 & 2.400000 & 20.40000 & 15.09000 & 0.630000 & 4.670000 \\
Std. Dev. & 0.411874 & 2.297622 & 3.045062 & 80.29253 & 4.413497 & 0.323436 & 7.877637 \\
Skewness & -0.811123 & -0.523108 & 0.899572 & 0.362023 & 0.024311 & -0.918607 & 0.009957 \\
Kurtosis & 2.679967 & 2.375891 & 2.902415 & 2.007164 & 2.292980 & 2.598213 & 1.976223 \\
Jarque-Bera & 1.594894 & 0.865714 & 1.893757 & 0.880812 & 0.292974 & 2.063127 & 0.611635 \\
Probability & 0.450478 & 0.648653 & 0.387950 & 0.643775 & 0.863737 & 0.356449 & 0.736521 \\
Sum & 100.1877 & 96.89000 & 82.01000 & 1865.480 & 322.5600 & 17.44000 & 233.1600 \\
Sum Sq. Dev. & 2.205317 & 68.62789 & 120.5412 & 83809.58 & 253.2264 & 1.359943 & 806.7431 \\
Observations & 14 & 14 & 14 & 14 & 14 & 14 & 14 \\
\hline
\end{tabular}

Source: Author's EView 8.0 Computation

Table 6 also shows the mean, median, maximum and minimum as well as deviations from the mean of the series. In this case, skewness coefficients show that all the variables have values less than 1 . This indicates a normal frequency distribution for all the variables under study. Kurtosis coefficients also support to this position with values not greater than 3 for all variables. There is no significant p-value for Jarque-Bera statistic, indicating normal distribution for the variables. Market price of shares, in this case, also reveals a very volatile standard deviation. 
Table 7.Regression Analysis- Guinness Nigeria PlcDependent Variable: Log of Retained Earnings

\begin{tabular}{lrcrc}
\hline Variable & Coefficient & Std. Error & t-Statistic & Prob. \\
\hline DEPS & 0.002992 & 0.021758 & 0.137504 & 0.8951 \\
DMPS & -0.000782 & 0.002620 & -0.298503 & 0.7754 \\
DDPS & -0.045561 & 0.037046 & -1.229856 & 0.2648 \\
DNAVPS & -0.030766 & 0.024912 & -1.234997 & 0.2630 \\
DPERATIO & -0.054507 & 0.022900 & -2.380180 & 0.0548 \\
DCAR & -0.069229 & 0.558683 & -0.123914 & 0.9054 \\
C & 0.242275 & 0.084828 & 2.856093 & 0.0289 \\
R-squared & 0.726358 & Mean dependent var & & 0.071596 \\
Adjusted R-squared & 0.452717 & S.D. dependent var & & 0.325689 \\
S.E. of regression & 0.240940 & Akaike info criterion & & 0.295198 \\
Sum squared resid & 0.348313 & Schwarz criterion & & 0.599401 \\
Log likelihood & 5.081214 & Hannan-Quinn criter. & & 0.232670 \\
F-statistic & 2.654416 & Durbin-Watson stat & & 2.746138 \\
Prob(F-statistic) & 0.130003 & & & \\
\hline
\end{tabular}

Source: Author's EView 8.0 Computation

Equation: Retained Earnings $=0.242275+0.002992(\mathrm{EPS})-0.000782(\mathrm{MPS})-0.045561(\mathrm{DPS})$

$$
\text { - 0.030766(NAVPS) - 0.054507(PE RATIO) - 0.069229(CAR) + et }
$$

Table 7indicates that negative and insignificant relationships exist between retained earnings and market price of shares, dividend per share, net asset value per share, price-to-earnings ratio and current asset ratio while retained earnings share positive and insignificant relationship with earnings per share. Adjusted $\mathrm{R}^{2}$ reveals that about $45.3 \%$ of the variations in retained earnings could be explained by the independent variables.

Table 8.Correlation Results- Guinness Nigeria Plc

\begin{tabular}{crlllrrc}
\hline & DLOGRE & \multicolumn{1}{c}{ DEPS } & \multicolumn{1}{c}{ DDPS } & \multicolumn{1}{c}{ DMPS } & DNAVPS & DPERATIO & DCAR \\
\hline DLOGRE & 1.000000 & -0.03355 & -0.10514 & -0.651975 & 0.122657 & -0.743031 & 0.201698 \\
DEPS & -0.033550 & 1.000000 & 0.139836 & -0.130613 & 0.108158 & -0.029454 & 0.081501 \\
DDPS & -0.105149 & 0.139836 & 1.000000 & -0.082934 & -0.326566 & -0.173587 & -0.55515 \\
DMPS & -0.651975 & -0.13061 & -0.08293 & 1.000000 & -0.065155 & 0.678430 & -0.13050 \\
DNAVPS & 0.122657 & 0.108158 & -0.32656 & -0.065155 & 1.000000 & -0.404945 & -0.07974 \\
DPERATIO & -0.743031 & -0.02945 & -0.17358 & 0.678430 & -0.404945 & 1.000000 & 0.049351 \\
DCAR & 0.201698 & 0.081501 & -0.55515 & -0.130501 & -0.079745 & 0.049351 & 1.000000 \\
\hline
\end{tabular}

Source: Author's EView 8.0 Computation

Table 8 indicates a positive correlation between retained earnings and current asset ratio and net asset value per share and a negative correlation with earnings per share, dividend per share and market price per share and price-to-earnings ratio. A strong relationship was found between retained earnings and market value of shares (about $65 \%$ ) and price-to-earnings ratio (about 74\%). Other variables indicate weak relationships with retained earnings.

\subsection{Analysis of pooled data of the Brewery Industry}

Table 9.Descriptive Statistics- Industry

\begin{tabular}{lccccccc}
\hline & LOGRE & EPS & DPS & MPS & CAR & NAVPS & PERATIO \\
\hline Mean & 7.241228 & 4.892857 & 3.946071 & 15.45321 & 1.045714 & 15.45321 & 20.91714 \\
Median & 7.294263 & 4.700000 & 3.000000 & 14.97500 & 1.050000 & 14.97500 & 19.41500 \\
Maximum & 8.016865 & 9.950000 & 12.80000 & 30.57000 & 1.620000 & 30.57000 & 63.88000 \\
Minimum & 6.235229 & 0.770000 & 0.550000 & 3.740000 & 0.150000 & 3.740000 & 4.670000 \\
Std. Dev. & 0.416146 & 2.843693 & 2.992062 & 8.696517 & 0.394259 & 8.696517 & 11.58870 \\
Skewness & -0.292348 & 0.244506 & 1.296965 & 0.123277 & -0.251032 & 0.123277 & 1.759963 \\
Kurtosis & 2.775426 & 1.854772 & 4.220158 & 1.648071 & 2.153501 & 1.648071 & 7.829653 \\
Jarque-Bera & 0.457685 & 1.809126 & 9.586800 & 2.203250 & 1.130067 & 2.203250 & 41.66799 \\
Probability & 0.795454 & 0.404719 & 0.008284 & 0.332331 & 0.568341 & 0.332331 & 0.000000 \\
Sum & 202.7544 & 137.0000 & 110.4900 & 432.6900 & 29.28000 & 432.6900 & 585.6800 \\
Sum Sq. Dev. & 4.675796 & 218.3380 & 241.7157 & 2041.994 & 4.196886 & 2041.994 & 3626.043 \\
Observations & 28 & 28 & 28 & 28 & 28 & 28 & 28 \\
\hline
\end{tabular}

Source: Author's EView 8.0 Computation 
The mean, median, maximum and minimum as well as deviations from the mean of the series are shown in Table 9. In this case, skewness coefficients show that all the variables except dividend per share and price-to-earnings ratio have values less than 1 . This indicates a normal frequency distribution for all the variables except dividend per share and price-to-earnings ratio. This position is supported by Kurtosis coefficients with 4.220158 for DPS and 7.829653 for PE Ratio and Jarque-Bera statistic with significant p-value of 0.008284 for DPS and 0.000000 for PE Ratio. Price-to-earnings ratio reveals a more volatile standard deviation followed by MPS and NAVPS with equal coefficient.

The Augmented Dickey Fuller test for unit root adopted by the research was applied on the sectoral time series data obtained from annual report and accounts of Nigerian Breweries Plc and Guinness Nigeria Plc to determine the stationary status. The result of the test is shown below.

Table 10.Augmented Dickey Fuller (ADF) Unit Root Test Results-Brewery Industry

\begin{tabular}{lccccl}
\hline Variables & \multicolumn{3}{c}{ Test Critical Values } & Test Statistics & \multicolumn{1}{c}{ Status } \\
\hline & $1 \%$ & $5 \%$ & $10 \%$ & ADF & (Stationary) \\
LOGRET.EARN & -3.711457 & -2.981038 & -2.629906 & -6.227849 & $\mathrm{I}(1)$ \\
EPS & -3.769597 & -3.004861 & -2.629906 & -5.065441 & $\mathrm{I}(1)$ \\
NAVPS & -3.711457 & -2.981038 & -2.629906 & $-5.621229 *$ & $\mathrm{I}(1)$ \\
P/E Ratio & -3.711457 & -2.981038 & -2.629906 & -5.028028 & $\mathrm{I}(1)$ \\
Share Price-MPS & -3.711457 & -2.981038 & -2.629906 & $-5.621229 *$ & $1(1)$ \\
CAR & -3.711457 & -2.981038 & -2.629906 & -6.014411 & $1(1)$ \\
DPS & -3.711457 & -2.981038 & -2.629906 & -8.008190 & $1(1)$ \\
\hline
\end{tabular}

Source: Researcher's EView 8.0 Computation

Table 10 indicates that all the variables have unit root but attained stationary at first difference. The variables are all integrated in the same order signifying a co-integration among the variables under study as opine by Engle and Granger (1985). They argue that when time series data are integrated of the same order I(1), the data series tend to co-integrate. This implies that their short run relationship is sustainable in the long run.

Table 11.Regression Analysis Industry

Dependent Variable: Retained Earnings

\begin{tabular}{|c|c|c|c|c|}
\hline Variable & Coefficient & Std. Error & t-Statistic & Prob. \\
\hline DEPS & 0.011366 & 0.030606 & 0.371355 & 0.7141 \\
\hline DDPS & -0.019560 & 0.033033 & -0.592129 & 0.5601 \\
\hline DMPS & 0.019145 & 0.023001 & 0.832352 & 0.4146 \\
\hline DPERATIO & 0.006302 & 0.006726 & 0.937030 & 0.3594 \\
\hline DCAR & -0.297704 & 0.203000 & -1.466525 & 0.1573 \\
\hline $\mathrm{C}$ & 0.013623 & 0.075024 & 0.181575 & 0.8577 \\
\hline $\begin{array}{l}\text { R-squared } \\
\text { Adjusted }\end{array}$ & 0.177403 & \multicolumn{2}{|c|}{ Mean dependent var } & 0.032945 \\
\hline $\begin{array}{l}\text { R-squared } \\
\text { S.E of }\end{array}$ & -0.018454 & \multicolumn{2}{|c|}{ S.D. dependent var } & 0.370608 \\
\hline regression & 0.374012 & \multirow{2}{*}{\multicolumn{2}{|c|}{ Akaike info criterion }} & 1.064072 \\
\hline $\begin{array}{l}\text { Sum squared } \\
\text { resid }\end{array}$ & 2.937585 & & Schwarz criterion & 1.352036 \\
\hline Log likelihood & -8.364977 & \multicolumn{2}{|c|}{ Hannan-Quinn criter. } & 1.149699 \\
\hline F-statistic & 0.905778 & \multirow{2}{*}{\multicolumn{2}{|c|}{ Durbin-Watson stat }} & 2.384291 \\
\hline Prob(F-statistic) & 0.495876 & & & \\
\hline
\end{tabular}

Source: Author's EView 8.0 Computation

$$
\begin{array}{r}
\text { Equation: Retained Earnings }=0.013623+0.011366(\mathrm{EPS})-0.019560(\mathrm{DPS})+0.019145(\mathrm{MPS}) \\
+0.006302(\mathrm{PE} \text { RATIO })-0.297704(\mathrm{CAR})+\operatorname{et}(3)
\end{array}
$$

Table 11indicates that negative and insignificant relationships exist between retained earnings and dividend per share and current asset ratio. A positive and insignificant relationship exists between retained earnings and earnings per share, market price of shares and price-to-earnings ratio.Net asset value per share was dropped because of its collinearity with market price of equity shares. 
Table 12.Correlation Results- Industry

\begin{tabular}{crrrrrrr}
\hline & LOGRE & \multicolumn{1}{c}{ EPS } & \multicolumn{1}{c}{ DPS } & \multicolumn{1}{c}{ MPS } & \multicolumn{1}{c}{ CAR } & PERATIO & \multicolumn{1}{c}{ NAVPS } \\
\hline LOGRE & 1.000000 & 0.186046 & 0.179985 & -0.004027 & -0.469283 & 0.239505 & -0.004027 \\
EPS & 0.186046 & 1.000000 & 0.684248 & 0.795176 & 0.289442 & -0.338964 & 0.795176 \\
DPS & 0.179985 & 0.684248 & 1.000000 & 0.700731 & 0.043715 & -0.168836 & 0.700731 \\
MPS & -0.004027 & 0.795176 & 0.700731 & 1.000000 & 0.368053 & -0.297034 & 1.000000 \\
CAR & -0.469283 & 0.289442 & 0.043715 & 0.368053 & 1.000000 & -0.629609 & 0.368053 \\
PERATIO & 0.239505 & -0.338964 & -0.168836 & -0.297034 & -0.629609 & 1.000000 & -0.297034 \\
NAVPS & -0.004027 & 0.795176 & 0.700731 & 1.000000 & 0.368053 & -0.297034 & 1.000000 \\
\hline
\end{tabular}

Source: Author's EView 8.0 Computation

Table 12 reveals a positive correlation between retained earnings, earnings per share, dividend per share and price-to-earnings ratio and a negative correlation with market price per share, current asset ratio and net asset value per share. A strong relationship (about 47\%) is found between retained earnings and current asset ratio and between retained earnings. Other variables show weak relationships with retained earnings. There is a perfect correlation between market price of shares and net asset value per share which is not healthy.

\subsection{Discussion of Results}

This paper evaluated the degree, magnitude and strength of the relationships between corporate retentions as represented by retained earnings and key financial performance indicators, as represented by earnings per share, price-to-earnings ratio, net asset value per share, market price of equity shares, dividend per share and current asset ratio in the Nigeria brewery sector. The research made use of secondary data obtained from annual account and records of the two market leaders in the sector, Nigeria Breweries Plc and Guinness Nigeria Plc, from year 2000 to 2013.These companies were chosen because of their consistent dominance trading activities at the Nigeria stock exchange. The magnitude of association of the variables was validated using the ordinary least squares method, modeled in form of multiple regression. Augmented Dickey- Fuller (ADF) test was conducted on all the variables to check for stationary of time series data. Log of retained earnings, current asset ratio, and dividend per share attained stationary at first difference, while earnings per share, net asset value per share, price -to- earnings ratio and market price of equity shares, achieved stationary at second difference. The result is in concordance with (Doepke, 2004; Daniels et al, 2007 and Dominguez, 2011). Furthermore, the Result indicates that a negative and significant relationship exists between retained earnings and current asset ratio which refutes Dominguez, (2011) and agrees with Iga (2008). A strong relationship (about 68\%) is found between retained earnings and current asset ratio and between retained earnings and provision for depreciation (about 77\%) agreeing with (Doepke, 2004; Thirumalaisamy, 2013; and Shayne, 2013). The implication of the results therefore is that long run relationship exists between retained earnings, provision for depreciation and the rest of the variables. Retained earnings have played very significant role in the boosting firm financial performance and can be explored by management to enhance return on investments of shareholders without diluting corporate control of the shareholders.

\subsection{Summary and Conclusion}

The importance of retained earnings and other corporate retentions to investment, expansion and diversification needs of firms in the brewery industry cannot be over emphasized. The industry is a capital intensive one as a result of the heavy equipments required to power, drive and sustain its production lines and other productive activities. In the course of time, the existing lines go bad requiring either maintenance or outright replacement and even automation to reduce man-hours and by extension, labour cost. A calculated attempt is therefore necessary to ensure the availability of funds as at when due. This will definitely help in reducing stock out and other related and relevant costs.

The costs of excess liquidity and its relationship with profitability should be taking into consideration in deciding the magnitude and strength of investment of corporate retentions. The reserves and other retentions should be invested to earn a good return for the shareholders and to ultimately grow the firm. The study is significant to Boards, management, individual and institutional investors and corporate policy and decision makers generally.

The outcome of the research accords to a large extent with our a priori expectations. At firm level, it was revealed that in Nigeria Breweries Plc, a negative and significant relationship exists between dividend per share and retained earnings. In Guinness Nigeria Plc, the relationship between retained earnings and earnings per share, market share price and current ratio was significant at $5 \%$ level. The industry analysis show that a negative and significant relationship exists between retained earnings and current asset ratio. In Nigeria Breweries Plc, a very strong relationship (87.5\%) is found between retained earnings and dividend per share and market value of shares $(66.2 \%)$ and net asset value per share (56.2\%).

The implication of the findings of this research is that reserves in terms of retained earnings are avenue for 
accumulating almost a cost free fund for investment purposes. Retentions also provide the company management with internally generated fund without cut-throat interest rate or diluting the control or ownership structure of the company. If this internally generated revenue is invested properly, it will act as catalyst for growth, development and expansion of firms in the Nigeria brewery industry. The indicators will serve as predictors to the appropriate levels of reserves and retentions which could guarantee good bottom line without incurring the costs of excess liquidity.

\section{References}

DeAngelo, H., L. DeAngelo \&Stulz, R. M. (2006). Dividend policy and the earned/contributed capital mix: a test of the life-cycle theory. Journal of Financial Economics, 81, 227-254.

Daniel, N., Denis, D. \& Naveen, L. (2007).Do Firms Manage Earnings to Meet Dividend Thresholds? Journal of Accounting and Economics www.elsevier.com/locate/jae 45 (2008) 2-26

Dickey, D. A.,\& Fuller, W. A. (1979). Distribution of the Estimators for Autoregressive Time Series with a UnitRoot.Journal of the American Statistical Association, 74, 427-431.

Doepke, M. (2004). Show Me the Money: Retained Earnings and the Real Effects of Monetary Shocks, http://sites.uclouvain.be/econ/DP/REL/2005011.pdf

Dominguez, K. (2011). International Reserves and the Global Financial Crisis, Nber Working Paper Series, National Bureau of Economic Research Working Paper 17362 http://www.nber.org/papers/w17362

Donaldson, C.(1961). Corporate debt capacity; a study of corporate debt policy and the determination of Corporate debt capacity. http://www.worldcat.org/ Harvard University.

Dutta, S.,\&Reichelstein, S. (2001). Controlling Investment Decisions: Depreciation and Capital Charges

Engle, R. F.,\& Granger, C. W. J. (1987). Co-Integration and Error-Correction: Representation, Estimation and Testing, Econometrica, 55, 251-276.

Granger; C.W.J (1969), Some recent developments in a concept of causality, Journal of Econometrics, 39: $199-211$.

Iga (2008).Depreciation and Related Issues June, Financial Sustainability Program, Information Paper 17, LGA 'Depreciation and Related Issues' Information Paper, http://www.lga.sa.gov.au/webdata/resources/files/LGA-37989

Johansen, S. (1991)Estimation and Hypothesis Testing of Cointegrating Vectors in Gaussian VectorAutoregressive Models, Econometrica,59, 1551-80.

Khan, H. S. (2009).Determinants of Share Price Movements in Bangladesh: Dividends and Retained Earnings, Thesis for the degree of MSc. in Business Administration, School of Management, Blekinge Institute of Technology, Spring. http://www.sea-mist.se/fou/cuppsats.nsf/all/70Version.pdf

Kim, B., \&Suh, J. (2010).Retained Earnings and Capital Structure, http://media.csmfo.org/wp-content/uploads/2010

Mikkelson, W., \& Megan P.(2003). Do persistent large cash reserves hinder performance? Journal of Financial and Quantitative Analysi,38(2), 275-294.

Modigliani, F., \& Miller, M., (1958) "The Cost of Capital, Corporation Finance and the theory of investment",The American Economic Review, 48(3), 261-297.

Myers, S. \&Majluf,N. (1984). Corporate financing and investment decisions when firms have information thatInvestors do not have. Journal of Financial Economics 13, 187-221.

Nwude, C. (2007). Valuation and Pricing of Equity Securities in an Emerging Stock Market:Evidence fromNigerian Banking Sector (2007). http://ssrn.com/abstract=1649439 or http://dx.doi.org/10.2139/ssrn.1649439

Onuorah, A., \&Ezeji, E.C.(2013). A Comparative Analysis of the Impact of Corporate Taxation OnCompany's Reserve and Dividend Policy in Nigeria: 2000-2011, Developing Country study, InternationalKnowledge Sharing Platform, $3(1)$.

Thirumalaisamy, R. (2013). Firm Growth and Retained Earnings Behavior - A Study on Indian Firms, EuropeanJournal of Business and Management, 5(27).

Thorntorn, G. (2010). Maintaining sufficient reserves to protect your not-for-profitorganization,www.elsevier.com/locate/jae

Onojah A, L. \&Unegbu, A. (2013). Review of Accounting Gimmicks Called Depreciation, Open Journal ofAccounting, 2, 39-44.

Segal, U \&Spivak, A. (1985). Firm Size and Optimal Growth Rates, UCLA Working Paper380, 
http://www.econ.ucla.edu/workingpapers/wp380.pdf.

Shayne,K. (2013). Sizing your Reserves: How much is Enough, Government Finance Officers Association, $107^{\text {th }}$ GFOA Annual Conference, Bridges to financial sustainability, http://media.csmfo.org/wp-content/uploads/2013/06/fund-reserve-gfoa-national.pdf

Tsuji, C. (2012). Does EVA beat earnings and cash flow in Japan? Applied Finance Deniescial Economics, 16, 1199-1216

Wu, X., \&Yeung, C. K.(2010). A Growth Type Explanation for Persistence in Retained Earnings and Propensity to Pay Dividends, Working paper, City University of Hong Kong.

\section{$(\mathrm{cc}) \mathrm{EY}$}

This work is licensed under a Creative Commons Attribution 3.0 License. 